\title{
PERANAN GURU DALAM PENDIDIKAN KARAKTER
}

\author{
Titin Triana
}

Sekolah Menengah Atas (SMA) PGRI Tembilahan

\begin{abstract}
Character education is a system of instilling character values including knowledge, awareness, and actions to implement these values to the Almighty God, ourselves, others, the environment, human and nationality to become perfect man. Character education is an effort that should involve all parties, the household and the family, the school and the school environment, the community at large. It is used to improve the quality of the implementation and education results leading to the achievement of character building and morals that are holistic, integrated and balanced. This can be integrated in the learning in each subject. Instructional material relating to norms or values on each subject needs to be developed explicitly associated with the daily context. Character education can build national awareness and encourage students' innovation and creativity. Beside, the values that must be built within the next generation are honesty, hard works, respect, cooperation, tolerance and discipline. In addition, the development of learner's potentials can create a faithful man and fear of God Almighty, noble, healthy, knowledgeable, skilled, creative, independent, and democratic and responsible citizens. The formulation of these objectives reflects the growing expectations of the various parties to the education as the social agent instrument of human resource development.
\end{abstract}

Keyword: Supervision; Principal; Teacher Professionalism

Copyright (C) 2016 Madrasah Jurnal Pendidikan dan Pembelajaran Dasar. All Right Reserved

\section{A. PENDAHULUAN}

Undang-Undang Republik Indonesia Nomor 20 Tahun 2003 tentang Sistem Pendidikan Nasional pasal 4 menggariskan bahwa pendidikan nasional bertujuan untuk mengembangkan potensi peserta didik agar menjadi manusia yang beriman dan bertakwa kepada Tuhan Yang Maha Esa, berakhlak mulia, sehat, berilmu, cakap, kreatif, mandiri dan menjadi warga Negara yang demokratis serta bertanggung jawab.

Rumusan tujuan tersebut mencerminkan semakin besarnya harapan berbagai pihak terhadap pendidikan sebagai instrument utama pengembangan sumber daya manusia. Pendidikan merupakan elemen penting dari kehidupan seseorang dan merupakan aspek startegis bagi suatu Negara. Sifat pendidikan adalah kompleks, dinamis dan kontekstual. Kompleksitas pendidikan ini menggambarkan bahwa pendidikan itu adalah sebuah upaya yang serius karena pendidikan melibatkan aspek kognitif, afektif, psikomotorik yang akan membentuk diri seseorang secara keseluruhan menjadi manusia seutuhnya.

Pendidik merupakan tenaga professional yang bertugas merencanakan dan melaksanakan proses pembelajaran, menilai hasil pembelajaran, melalukuan pembimbingan dan pelatihan serta melakukan penelitian dan pengabdian kepada masyarakat terutama bagi pendidik pada perguruan tinggi (Pasal 39 (2) UU Nomor 20 Tahun 2003).

Vol. 9 No. 1, Desember 2016

Madrasah homepage: http://ejournal.uin-malang.ac.id/index.php/madrasah/index 


\section{MADRASAH}

Jurnal Pendidikan dan Pembelajaran Dasar

p ISSN: 1979-5599 | e ISSN: 2502-194X

P a g e

Guru sebagai figur sentral dalam pendidikan haruslah dapat diteladani akhlaknya di samping kemampuan keilmuan dan akademisnya. Selain itu guru haruslah mempunyai tanggung jawabdan keagamaan untuk mendidik anak didiknya menjadi orang yang berilmu dan berakhlak (Syed Hossein Nasr dalam Ayumardi Azra).

Guru adalah elemen yang penting dalam proses pembelajaran di kelas, sebab guru adalah penanggung jawab utama dalam proses pembelajaran. Melihat posisi guru yang sangat strategis dalam proses pembelajaran ini, maka guru harus mempunyai kompetensi yang memadai dalam melaksanakan proses pembelajaran.

Guru yang berkualitas adalah guru yang mampu membelajarkan peserta didiknya dalam keterbatasan sarana dan prasaranan. Adalah tugas mulia guru untuk melahirkan lulusan yang bermutu sesuai dengan kebutuhan penyelenggaran, jalur, jenis dan jenjang pendidikan. Dengan kata lain guru mempunyai tugas yang amat mulia dalam upaya kelangsungan hidup bangsa dan Negara.

Status guru mempunyai implikasi terhadap peran dan fungsi yang menjadi tanggung jawabnya. Guru memiliki satu kesatuan peran dan fungsi yang tidak terpisahkan antara kemampuan mendidik, membimbing, mengajar dan melatih. Keempat kemampuan tersebut merupakan kemampun integrative, yang satu tidak dapat dipisahkan dengan yang lain. Misalnya seseorang yang dapat mendidik tetapi tidak memiliki kemampuan membimbing, mengajar dan melatih maka ia tidak dapat disebut sebagai guru yang paripurna. Seterusnya seseorang yang memiliki kemampuan mengajar, tetapi tidak memiliki kemampuan mendidik, membimbing dan melatih, juga tidak dapat disebut sebagai guru sebenarnya. Guru harus memiliki kemampuan keempat-empatnya secara paripurna. Karena kemampuan tersebut secara terminologis akademis dapat dibedakan antara satu dengan yang lain. Namun dalam kenyataan praktik di lapangan, keempat hal tersebut harus menjadi satu kesatuan utuh yang tidak dapat dipisah-pisahkan.

Meskipun demikian, seorang guru adalah manusia biasa, ia sama sekali bukan manusia super yang tanpa cacat. Guru adalah manusia biasa yang sekalius memiliki kelebihan dan kekurangan. Itulah sebabnya keempat kemampuan yang harus dimiliki oleh seorang guru berada dalam gradasi yang beraneka ragam.

\section{B. PERAN DAN FUNGSI GURU}

Secara komprehensif guru harus memiliki keempat kemampuan tersebut secara utuh, meski ada kemampuan mendidik harus lebih dominan dibandingkan dengan kemampuan yang lainnya. Sesuai dengan fokus kemampuannya dapat disebut beberapa macam guru misalnya guru pendidik, guru pembimbing, guru pengajar dan guru pelatih. Berdasarkan tanggung jawab yang diembannya, guru dapat dibedakan menjadi lima macam yakni:

1. Guru kelas, jika ia mempunyai tugas untuk mengajarkan sebagian besar mata pelajaran di satu kelas saja dan ia tidak mengajar dikelas lainnya.

2. Guru mata pelajaran, jika hanya memiliki tugas untuk mengajarkan satu mata pelajaran saja.

3. Guru bimbingan dan konseling yakni guru yang diberi tugas untuk memberikan bimbingan bagi peserta didik, baik dalam menghadapi kesulitan belajar maupun untuk memilih karir di masa depan yang sesuai dengan bakat dan minatnya.

4. Guru pustakawan yakni guru yang selain memiliki tugas utamanya, ia juga diberi tugas tambahan lain untuk mengurus perpustakaan sekolah.

Vol. 9 No. 1, Desember 2016

Madrasah homepage: http://ejournal.uin-malang.ac.id/index.php/madrasah/index 
5. Guru ekstrakulikuler yakni guru yang diberi tugas tambahan lain sebagai pembimbing kegiatan ekstrakulikuluer seperti Pembina pramuka, Pembina olah raga, Pembina kelompok ilmiah Remaja, seni music dan seni tari dan sebagainya.

Secara ideal seorang guru sebaiknya memang harus memiliki banyak pengetahuan dan keterampilan. Namun kompetensi akademik pokok yang harus dimiliki adalah sebagai guru pengajar, yakni lebih memiliki kemampuan dalam mentransfer ilmu pengetahuan dan teknologi kepada peserta didik. Adapun kemampuan yang lainnya sebagai kemampuan yang mendukung terhadap kemampuan utamanya tersebut.

Sebagai pendidik guru lebih banyak sebagai sosok panutan, yang memiliki nilai moral dan agama yang patut ditiru dan diteladani oleh siswa. Contoh dan keteladanan itu lebih merupakan aspek-aspek sikap dan perilaku, budi pekerti luhur dan ahlak mulia, seperti jujur, tekun, mau belajar, amanah, social dan sopan santun terhadap sesama. Sikap dan perilaku guru yang sehari-hari dapat diteladani oleh siswa di dalam maupun diluar kelas, merupakan alat pendidikan yang diharapkan akan membentuk kepribadian siswa kelak di masa dewasa. Dalam konteks inilah maka sikap dan perilaku guru menjadi semacam bahan ajar secara tidak langsung yang dikenal dengan hiden curriculum. Sikap dan perilaku guru menjadi bahan ajar yang secara langsung akan ditiru dan diikuti oleh para siswa. Dalam hal ini guru dipandang sebagai role model yang akan digugu dan ditiru oleh siswanya.

Sebagai pengajar guru diharapkan memiliki pengetahuan yang luas tentang disiplin ilmu yang harus diampu untuk ditransfer kepada siswa. Dalam hal ini guru harus menguasai materi yang akan diajarkan, menguasai penggunaan strategi dan metode mengajar yang akan digunakan untuk menyampaikan bahan ajardan menentukan alat evaluasi pendidikan yang akan digunakan untuk menilai hasil belajar siswa, aspek-aspek manajemen kelas dan dasar-dasar kependidikan.

Sebagai pembimbing guru juga perlu memiliki kemampuan untuk dapat membimbing siswa, memberikan dorongan psikologis agar siswa dapat menepikan factorfakto internal dan factor eksternal yang akan menganggu proses pembelajaran di dalam dan di luar sekolah serta memberikan arah dan pembinaan karir siswa sesuai dengan bakat dan kemampuan siswa.

Sebagai pelatih guru harus memberikan sebanyak mungkin kesempatan bagi siswa untuk dapat menerapkan konsepsi atau teori ke dalam praktik yang akan digunakan langsung dalam kehidupan. Dalam aspek ini guru perlu memberikan kesempatan seluasluasnya kepada siswa memperoleh pengalaman belajar yang sebanyak-banyaknnya khususnya untuk mempraktikkan berbagai jenis ketrampilan yang mereka butuhkan.

Dari sisi lain sering dicitrakan memiliki peran ganda yang dikenal sebaga EMASLIMDEF (Educator, Manager, Administrator, Supervisor, Leader, Inovator, Motivator, Dinamisator, Evaluator, Facilitator). EMASLIMDEF lebih merupakan peran kepala sekolah, tetapi dalam skala mikro di kelas, peran itu juga harus dimiliki oleh para guru.

Sebagai educator merupakan peran yang pertama dan utama khususnya untuk peserta didik dan pada jenjang pendidikan dasar (SD dan SMP). Peran ini lebih lanjut sebagai teladan bagi peserta didik sebagai role model, memberikan contoh dalam hal sikap dan perilaku, membentuk kepribadian peserta didik.

Sebagai manager, pendidik memiliki peran utama menegakkan ketentuan dan tata tertib yang telah disepakati bersama di sekolah memberikan arahan atau rambu-rambu ketentuan agar tata tertib di sekolah dapat dilaksanakan dengan sebaik-baiknya oleh seluruh warga sekolah.

Vol. 9 No. 1, Desember 2016

Madrasah homepage: http://ejournal.uin-malang.ac.id/index.php/madrasah/index 


\section{MADRASAH}

Jurnal Pendidikan dan Pembelajaran Dasar

p ISSN: 1979-5599 | e ISSN: 2502-194X

P a g e

Sebagai administrator guru memiliki peran untuk melaksanakan adminsitrasi sekolah seperti buku prestasi siwa, buku daftar nilai, buku rapor, administrasi kurikulum dan administrasi penilaian. Bahkan secara administratif para guru seyogyanya juga memiliki rencana mengajar, program semester dan program tahunan dan yang paling penting adalah menyampaikan rapor atau laporan pendidikan kepada orang tua siswa dan masyarakat. Sedang peran sebagai supervisor terkait dengan pemberian bimbingan dan pengawasan kepada peserta didik, memahami permasalahan yang dihadapi peserta didik, menemukan permasalahan yang terkait dengan prose pembelajaran, dan akhirnya memberikan jalan keluar pemecahan masalahnya. Peran sebagai leader bagi guru lebih tepat dibandingkan dengan peran sebagai manager, karena manager bersifat kaku terhadap ketentuan yan ada. Dari aspek penegakan disiplin, sebagai missal guru menekankan disiplin mati sementara sebagai leader lebih memberikan kebebasan secara bertanggung jawab kepada peserta didik. Dengan demikian disiplin yang ditegakkan oleh guru dari peran sebagai leader ini adalah disiplin hidup. Dalam melaksanakan peran sebagai innovator, seorang guru harus memiliki kemauan belajar yang cukup tinggi untuk menambah pengetahuan dan ketrampilannya sebagai guru. Tanpa adanya semangat belajar yang tinggi, mustahil guru dapat menghasilkan inovasi-inovasi yang bermanfaat untuk meningkatkan mutu pembelajaran di sekolah.

Adapun peran sebagai motivator terkait dengan peran sebagai educator dan supervisor. Untuk meningkatkan semangat dan gairah belajar yang tinggi, siswa perlu memiliki motivasi yang tinggi, baik motivasi dari dalam dirinya sendiri (intrinsic) maupun dari luar (ekstrinsik) yang utamanya berasal dari gurunya.

Dalam buku bertajuk Dinamika Sekolah dan Bilik Darjah, Kamaruddin Haji Husin (1993:8), memaparkan peran guru dalam berbagai aspek yaitu sebagai:

1. Pendidik tugas pokoknya mengembangkan kepribadian, membina budi pekerti.

2. Pengajar tugas pokoknya menyampaikan ilmu pengetahuan, melatih ketampilan, memberikan panduan atau petunjuk, paduan antara memberikan pengetahuan, bimbingan, dan ketrampilan.

3. Fasilitator tugas pokoknya memotivasi siswa, membantu siswa, membimbing siswa dalam proses pembelajaran di dalam dan diluar kelas, menggunakan strategi dan metode pembelajaran yang sesuai, menggunakan pertanyaan yang merangsang siswa untuk belajar, menyediakan bahan pengajaran, mendorong siswa untuk mencari bahan ajar, menggunakan ganjaran dan hukuman sebagai alat pendidikan.

4. Pembimbing tugas pokoknya memberikan petunjuk atau bimbingan tentang gaya pembelajaran siswa, mencari kekuataan dan kelemahan siswa, memberikan latihan, memberikan penghargaan kepada siswa, mengenal permasalahan yang dihadapi siswa dan menemukan pemecahannya, membantu siswa untuk menemukan bakat dan minat siswa (karir di masa depan), mengenal perbedaan individual siswa.

5. Pelayan tugas pokoknya memberikan pelayanan pembelajaran yang nyaman dan aman sesuai dengan perbedaan individual siswa, menyediakan fasilitas pembelajaran dari sekolah seperti ruang belajar, meja kursi, papan tulis, almari, alat peraga, dan papan pengumuman, memberikan layanan sumber belajar.

6. Perancang tugas pokoknya menyusun program pengajaran dan pembelajaran berdasarkan kurikulum yang berlaku, menyusun rencana mengajar, menentukan strategi dan metode pembelajaran sesuai dengan konsep PAKEM (Pembelajaran Aktif, Kreatif, Efektif dan Menyenangkan).

Vol. 9 No. 1, Desember 2016

Madrasah homepage: http://ejournal.uin-malang.ac.id/index.php/madrasah/index 
7. Pengelola tugas pokoknya melaksanakan administrasi kelas, melaksanakan presensi kelas, memilih strategi dan metode pembelajaran yang efektif.

8. Innovator tugas pokoknya menemukan strategi dan metode mengajar yang efektif, meningkatkan kemampuan dan ketrampilan dalam penggunaan strategi dan metode mengajar, mau mencoba dan menerapkan srategi dan metode pembelajaran yang baru.

9. Penilai tugas pokoknya menyusun tes dan instrument penilaian lain, melaksanakan penilian terhadap siswa secara objektif, mengadakan pembelajaran remedial, mengadakan pengayaan dalam pembelajaran.

Wright (1987) sebagaimana dikutip oleh Robiah Sidin (1993:8) dalam bukunya

Classroom Management menyatakan bahwa guru memiliki dua peran utama yakni:

1. The management role atau peran manajemen tugas utamanya mengetahui latar belakang siswa, social, ekonomi dan intelektual-akademis, mengetahui perbedaan individual siswa, potensi dan kelemahan siswa, termasuk gaya pembelajaran mereka.

2. The instructional role atau peran instruksional tugas utamanya memiliki pengetahuan,terampil dan professional, bertanggung jawab, disiplin dan produktif, menghargai dan kasih sayang terhadap siswa, memiliki nilai moral, prinsip kemanusiaan dalam semua langkahnya, memiliki sikap inovatif, kreatif, dan memahami perbedaan dan individualitas di kalangan siswa, menjadi contoh model bagi siswa apa yang dikatakan itulah yang dilakukan, menghargai dan peduli terhadap lingkungan serta memahami perkembangan dan penerapan ilmu pengetahuan dan teknologi dalam kehidupan modern.

Dari kedua peran ini guru dapat disebut sebagai manajer dan sekaligus sebagai intruktur. Selain kedua peran tersebut, guru juga memiliki fungsi yang lain di dalam kelas yaitu sebagai:

1. Pembimbing siswa dalam memecahkan kesulitan dalam pembelajaran.

2. Sumber yang dapat membantu memecahkan dan menjawab pertanyaan-pertanyaan siswa untuk menemukan jawaban atau memperoleh informasi lanjutan.

3. Penilai hasil belajar untuk menentukan perkembangan hasil belajar siswa serta untuk menentukan nilai siswa.

\section{PENTINGNYA PENDIDIKAN KARAKTER}

Indonesia saat ini sedang menghadapi dua tantangan besar yaitu desentralisasi atau otonomi daerah. Kedua tantangan tersebut merupakan ujian berat yang harus dilalui dan dipersiapkan oleh seluruh bangsa Indonesia. Kunci sukses dalam menghadapi tantangan berat itu terletak pada kualitas sumberdaya manusia (SDM) Indonesia yang handal dan berbudaya. Oleh karena itu peningkatan kualitas SDM sejak dini merupakan hal penting yang harus dipikirkan secara sungguh-sungguh.

Karakter bangsa merupakan aspek penting dari kualitas SDM karena kualitas karakter bangsa menentukan kemajuan suatu bangsa. Pembentukan karakter harus dilakukan secara sistematis dan berkesinambungan yang melibatkan aspek knowledge, feelling, loving dan action.

Untuk dapat memahami pendidikan karakter itu sendiri, perlu memahami struktur antropologis yang ada dalam diri manusia (Koesoema A, 2007:80). Struktur antropologis manusia terdiri atas jasad, ruh, akal. Hal ini selaras dengan pendapat Lickona (1992) yang menekankan tiga komponen karakter yang baik, yaitu moral knowing (pengetahuan tentang moral), moral feeling (perasaan tentang moral) dan moral action (perbuatan moral), yang diperlukan agar anak mampu memahami, merasakan dan mengerjakan nilai-nilai kabijakan. Isitilah lainnya kognitif, afektif, dan psikomotorik. Untuk itu dalam pendidikan

Vol. 9 No. 1, Desember 2016

Madrasah homepage: http://ejournal.uin-malang.ac.id/index.php/madrasah/index 


\section{MADRASAH}

Jurnal Pendidikan dan Pembelajaran Dasar

p ISSN: 1979-5599 | e ISSN: 2502-194X

P a g e

karakter harus mencakup semua struktur antropologis manusia tersebut. Maka karakter yang paling ideal adalah intelektual profetik yang memiliki karakter:

1. Sadar sebagai mahluk ciptaan Tuhan.

2. Cinta Tuhan.

3. Bermoral.

4. Bijaksana.

5. Pembelajar sejati.

6. Mandiri.

7. Kontributif.

Dalam mewujudkan pendidikan karakter tidak dapat dilakukan penanaman nilainilai (Azra, 2002:175). Terdapat Sembilan pilar karakter yang berasal dari nilai-nilai luhur universal yaitu:

1. Karakter cinta Tuhan dan segenap ciptaan-Nya

2. Kemandirian dan tanggungjawab

3. Kejujuran/amanah, diplomatis

4. Hormat dan santun

5. Dermawan, suka tolong menolong dan gotong royong/kerjasama

6. Percaya diri dan pekerja keras

7. Kepemimpinan dan keadilan

8. Baik dan rendah hati

9. Karakter toleransi kedamaian dan kesatuan

Thomas Lickona (1991) mendefinisikan orang yang berkarakter sebagai sifat alami seseorang dalam meresppon situasi secara bermoral, yang dimanifestasikan dalam tindakan nyata melalui tingkah laku yang baik, jujur, bertanggung jawab, menghormati orang lain dan karakter mulia lainnya. Pengertian ini mirip dengan apa yang diungkapkan oleh Aristoteles bahwa karakter itu erat kaitannya dengan habit atau kebiasaan yang terus menerus dilakukan.

Pendidikan karakter mengajarkan kebiasaan cara berfikir dan perilaku yang membantu individu untuk hidup dan bekerja bersama sebagai keluarga, masyarakat dan bernegara dan membantu mereka untuk membuat keputusan yang dapat dipertanggungjawabkan. Tidak perlu disangsikan lagi bahwa pendidikan karakter merupakan upaya yang harus melibatkan semua pihak baik rumah tangga dan keluarga, sekolah dan lingkungan sekolah, masyarakat luas. Pendidikan karakter melalui sekolah tidak semata-mata pembelajaran pengetahuan semata, tetapi lebih dari itu, yaitu penanaman moral, nilai-nilai etika, estetika, budi pekerti yang luhur dan sebagainya. Pemberian penghargaan kepada yang berprestasi dan hukuman kepada yang melanggar, menumbuhsuburkan nilai-nilai yang baik dan sebaliknya mengecam dan mencegah berlakunya nilai-nilai yang buruk. Selanjutnya menerapkan pendidikan berdasarkan karakter dengan menerapkan ke dalam setiap pelajaran yang ada disamping mata pelajaran khusus untuk mendidik karakter seperti pelajaran Agama, Sejarah, Kewarganegaraan dan sebagainya.

Guru adalah profesi yang mulia, mendidik dan mengajarkan pengalaman baru bagi anak didiknya. Apa yang membuat guru dikatakan hebat? Kualitas apa yang diharapkan pada diri seorang guru menurut orang tua dan siswa? ada beberapa tips bagaimana menjadi guru berkarakter yang hebat:

Vol. 9 No. 1, Desember 2016

Madrasah homepage: http://ejournal.uin-malang.ac.id/index.php/madrasah/index 
1. Mencintai anak. Cinta yang tulus kepada anak adalah modal awal mendidik anak. Guru menerima anak didiknya apa adanya, mencintai tanpa syarat dan mendorong anak untuk melakukan yang terbaik pada dirinya. Penampilan yang penuh cinta adalah dengan senyum, sering tampak bahagia dan menyenangkan dan pandangan hidupnya positif.

2. Bersahabat dengan anak dan menjadi tauladan bagi anak. Guru harus bisa digugu dan ditiru oleh anak. Oleh karena itu, setiap apa yang diucapkan di hadapan anak harus benar dari sisi apa saja: keilmuwan, moral, agama, budaya. Cara penyampainnya pun harus menyenangkan dan beradab. Ia pun harus bersahabat dengan anak-anak tanpa ada rasa kikuk, lebih-lebih angkuh. Anak senantiasa mengamati perilaku gurunya dalam setiap kesempatan.

3. Mencintai pekerjaan guru. Guru yang mencintai pekerjaannya akan senantiasa bersemangat. Setiap tahun ajaran baru adalah dimulainya satu kebahagiaan dan satu tantangan baru. Guru yang hebat tidak akanmerasa bosan dan terbebani. Guru yang hebat akan mencintai anak didiknya satu persatu, memahami kemampuan akademisinya, kepribadiannya, kebiasannya dan kebiasaan belajarnya.

4. Luwes dan mudah beradaptasi dengan perubahan. Guru harus terbuka dengan teknik mengajar baru, membuan rasa sombong dan selalu mencari ilmu. Ketika masuk ke kelas guru harus dengan pikiran terbuka dan tidak ragu mengevaluasi gaya mengajarnya sendiri, dan siap berubah jika diperlukan.

5. Tidak pernah berhenti belajar. Dalam rangka meningkatkan profesionalitasnya guru harus selalu belajar dan belajar. Kebiasaan membaca buku sesuai dengan bidang studinya dan mengakes informasi aktual tidak boleh ditinggalkan.

Apabila ciri-ciri tersebut dimiliki oleh guru alih-alih disebut sebagai guru yang berkarakter, tentu keresahan di dunia pendidikan tidak akan terjadi. Keresehan yang paling menonjol akhir-akhir ini adalah kekerasan guru terhadap siswa. Beban guru yang berat, kesejahteraan yang belum baik dan rendahnya kecerdasan emosional merupakan salah satu sebab mengapa guru bisa berbuat khilaf dengan jalan menebarkan aroma kekerasan di dalam kelas.

Guru sebagai ujung tombak pendidikan, memiliki peran yang sangat sentral dalam mewujudkan siswa yang berkarakter guru selain dituntut untuk menyampaikan materi, juga dituntut untuk menjadi guru, digugu dan ditiru yang sebenarnya. Guru harus bisa menanamkan moral, nilai-nilai etika, estetika, budi pekerti yang luhur. Memberi penghargaan kepada yang berprestasi, dan hukuman kepada yang melanggar, menumbursuburkan nilai-nilai yang baik dan sebaliknya mengecam dan mencegah berlakunya nilai-nilai yang buruk. Selanjutnya menerapkan pendidikan berdasarkan karakter dengan menerapkan ke dalam setiap pelajaran dan juga dalam kehidupan nyata.

\section{SIMPULAN}

1. Status guru mempunyai implikasi terhadap peran dan fungsi yang menjadi tanggung jawabnya. Guru memiliki satu kesatuan peran dan fungsi yang tidak terpisahkan, antara kemampuan mendidik, membimbing, mengajar danmelatih.

2. Ada beberapa tips untuk menjadi guru berkarakter yang hebat: mencintai anaka, bersahabat dengan anak dan menjadi teladan bagi anak, mencintai pekerjaan guru, luwes dan mudah beradaptasi dengan perubahan, tidak pernah berhenti belajar.

3. Pendidikan karakter merupakan upaya yang harus melibatkan semua pihak baik rumah tangga dan keluarga, sekolah dan lingkungan sekolah, masyarakat luas.

Vol. 9 No. 1, Desember 2016

Madrasah homepage: http://ejournal.uin-malang.ac.id/index.php/madrasah/index 


\section{MADRASAH}

Jurnal Pendidikan dan Pembelajaran Dasar

p ISSN: 1979-5599 | e ISSN: 2502-194X

4. Tujuan pendidikan karakter adalah untuk meningkatkan mutu penyelenggaraan dan hasil pendidikan yang mengarahkan pada percapaian pembentukan karakter dan akhlak mulai peserta didik secara utuh, terpadu dan seimbang.

5. Pendidikan karakter dapat diintegrasikan dalam pembelajaran pada setiap mata pelajaran. Materi pembelajaran yang berkaitan dengan norma atau nilai-nilai pada setiap mata pelajaran perlu dikembangkan, dieksplisitkan, dikaitkan dengan konteks kehidupan sehari-hari.

6. Pendidikan karakter dapat membangun wawasan kebangsaan serta mendorong inovasi dan kreasi siswa. Selain itu nilai-nilai yang perlu dibangun dalam diri generasi penerus bangsa secara nasional yakni kejujuran, kerja keras, menghargai pendapat, kerja sama, toleransi dan disiplin.

\section{REFERENSI}

Firdaus. (2011). The Powerful Points of Guru, Pusat Pengembangan Pendidikan. Pekanbaru: Univeritas Riau.

Rampan, Korrie Layun dan Matheus. (2005). Guru Pahlawan Tanpa Tanda Jasa, Bandung:tp. Muslich, Masnur. (2011). Pendidikan Karakter. Jakarta: Bumi Aksara

Sudjana, Nana. (2009). Dasar-Dasar Proses Belajar Mengajar. Bandung: Sinar Baru Algensida. Isjoni. (2007). Pengembangan Profesional Guru. Pekanbaru: Cendikia Insani

Suparlan. (2006). Guru sebagai Profesi. Yogyakarta: Hikayat

Sunarto. (2008). Perkembangan Peserta Didik. Jakarta: Rineka Cipta

Sanjaya, Wina. (2008). Kurikulum dan Pembelajaran. Bandung: Kencana

Jurnal Iptek Terapan Volume 6 No. 4 Desember 2012

Undang-Undang Guru dan Dosen Tahun 2005

Vol. 9 No. 1, Desember 2016

Madrasah homepage: http://ejournal.uin-malang.ac.id/index.php/madrasah/index 